\title{
Priorities for the Innovative Development of the Agro-Industrial Complex: Problems and Mechanism of Achievement
}

\author{
Otinova M.E.* \\ Research Institute of Economics and Organization of the \\ Agro-Industrial Complex of the Central Black Earth Region \\ of the Russian Federation \\ Voronezh, Russia \\ e-mail: 01maryina@gmail.com
}

\section{Popova E.A}

Research Institute of Economics and Organization of the Agro-Industrial Complex of the Central Black Earth Region of the Russian Federation

Voronezh, Russia

e-mail: marketing_dep@mail.ru

\author{
Charykova O.G. \\ Research Institute of Economics and Organization of the \\ Agro-Industrial Complex of the Central Black Earth Region \\ of the Russian Federation \\ Voronezh, Russia \\ e-mail:CHOG@yandex.ru
}

Nesterov M.S.

Research Institute of Economics and Organization of the Agro-Industrial Complex of the Central Black Earth Region of the Russian Federation

Voronezh, Russia

e-mail: marketing_dep@mail.ru

\begin{abstract}
Relevance of this research is determined by significance of innovation processes for ensuring high competitiveness of Russian agricultural enterprises, improvement of food governance and achievement of high standards of living of the Russian population. The paper considers theoretical and applied questions of innovative development of the agricultural industry, including a brief summary of approaches to defining the nature of innovation, establishing relation and content of innovation interests and priorities of innovation development of agriculture. Relevant problems were identified in implementing the modern innovative technologies in agricultural enterprises, such as low financial support, weak marketing of domestic innovative products, low innovation activity of small enterprises and a lack of qualified personnel in the field of innovation management. Analysis of the status of innovation activity in the Russian Federation has shown small scope of marketing and organization innovations in agriculture, reduction in the number of $R \& D$ organizations and cuts to the research workforce. Justifications are provided to a mechanism allowing reaching the priority objectives of the innovative agribusiness development, including organizational and economic measures aimed at digitalization of the agricultural industry, introduction of environmentally safe technologies, and development of hi-tech export-oriented enterprises. The proposed key development areas for activation of the innovative development of agriculture may be used in development of relevant strategies and sectoral development programs.
\end{abstract}

Keywords - innovative development, agribusiness, digitalization, innovative technologies, smart agriculture.

\section{INTRODUCTION}

The modern conditions of operation of the Russian agribusiness, which are characterized with strengthening of globalization processes, political sanctions, a threat of global food crisis due to the continuing pandemic, make it necessary to define new strategic goals and priorities for innovation devel- opment of the agribusiness as a main driver in development of the nation's economy capable of ensuring food security.

In the context of globalization and strengthening of intersector relations, agriculture is a foundation that determines development vectors for related industries: food and food processing industries, machine engineering, chemical industry, etc. Thus, digitalization of agribusiness gives most results if the innovations cover the agricultural system as a whole.

A solution of the problems arising due to global challenges of the world economy and economic shock is possible on the foundation of innovative breakthrough in agricultural sectors, namely, transition to digital agriculture (precision farming, digitalization of business processes, introduction of innovative forms of employment of rural population, etc.). Innovative development of agribusiness is a process of implementing innovative scientific developments in agricultural production sectors, at enterprises of food and processing industry, in logistic chains in order to attain high efficiency in operation and leading market positions.

Attaining the strategic goal of social and economic development of the country - transition to digital economy, ubiquitous implementation of innovations - is provided by means of using existing potential of a region and its rural territories. The main component of this potential is an economically active rural population, serving as the main competitive factor of success.

At that, the essential role and significance are given to innovation environment of agribusiness, development of which is being inhibited by a number of unfavorable factors. Animal farming is in a specific position here, as despite significant attention on behalf of the government, they continue using obsolete technologies, while innovative processes are implemented pointwise only at large enterprises that have not only 
sufficient financial resources, but also high quality personnel capable of operating digital technologies, as well as management and lead specialists receptive of innovations.

Despite the state innovation polity, there are a number of unresolved issues: first, it is a weak innovative activity of small agribusiness; innovations are practically unheard of in family farms; there are no financial nor organizational capabilities for application of new digital technologies. It leads to further consolidation of agribusiness, impoverishment of smallholder farmers and degradation of the countryside. The second issue is rather worn-off equipment and obsolete technologies still used in enterprises of food and processing industries. The foods produced often do not meet the world quality standards, making their export impossible. The third issue is scarcity of qualified personnel. In particular, young specialists and graduates of agricultural tertiary schools are not interested in being employed in agribusiness due to low image of living in the countryside and unattractive living conditions.

Despite a significant number of scientific studies addressing the issues in innovation activity in agriculture, scientific and technological development and breakthrough technologies happen fast, thus, the issues in innovative development of agriculture are constantly becoming relevant and requires development of tools which will be adequate to the challenges and external changes. The subject of the research is organizational and economic relations arising during the innovative development of agribusiness.

Theoretical and methodological foundation of the research is formed by scientific works of both Russian and foreign scientists covering the issues of innovative development, formation of national innovation systems, digitalization of agriculture, strategies and program documents of the government of the Russian Federation, scientific materials for various aspects of implementation of innovative technologies and robotics in agriculture.

Actualization of the research objective was attained by supplementing the theoretical provisions of innovative development in agribusiness, conducting analysis of the modern state of innovative activities and providing justifications for the mechanism of attaining priority targets in innovative development of agribusiness, including a set of tools to activate innovation processes, measures aimed at improvement of resource base of the innovation activity, as well as proposals aimed at stimulation of implementation of environmentally safe technologies that reduce environmental footprint of the innovative transformations in agribusiness.

Methodological foundation of the research is formed by general scientific and special methods of scientific cognition: abstract logical, dialectic, theoretical generalization, analysis and synthesis, functional analytic methods, as well as methods of economic statistics.

\section{LITERATURE REVIEW}

Numerous scientists in Russia and abroad contributed to studies of theoretical, methodological and applied aspects of innovative development and digitalization: A. Smith. D. Ricardo, T. Malthus, J. Bennal, M. Porter, P. Romer, B. Twiss, C. Freeman, J. Hicks, J. Schumpeter, R. Adukov, A. Altukhov,
V. Bautin, A. Golubev, T. Bondarenko, V. Zakshevskii, E. Krylatykh, V. Kundius, V. Nechaev, E. Ogloblin, I. Sandu, I. Khitskov, and others.

Representatives of the classical school of economic thought were first to expose the meaning of innovations as a factor of increasing workforce productivity. They held that knowledge allowing changing the industry and shaping the economic growth was an important economic resource [1]. Joseph Schumpeter founded the theory of innovative development, providing justifications for his theory of innovation and theory of economic development [2]. Understanding the importance of innovative development for all the areas of human activities led to increased activity of applied research in a number of questions pertaining to formation and actualization of innovative processes, development of innovation environment, etc. Three approaches to innovations were formed in the scientific community. An object approach to studying innovations consisted in representing innovations as a result of scientific and technological progress. A process approach understood innovation as a process of developing, implementing in production and advancement of new consumer values. Within the framework of systematic approach, a concept of innovative systems was formed, where the foundational provision is the leading role of educational and scientific environment in the efficient implementation of innovative processes [3-5].

Generalization of modern research allowed defining innovative development of agribusiness as a process of systemic and continuous qualitative transformation of all the areas of operation in agribusiness enterprises by means of innovative technologies that facilitate significant growth in production and economic indicators and expand market positions in both domestic and global agricultural markets.

Being a systemic process, innovative development, just like any other type of development that happens in accordance with the economic laws, takes place on the basis of a system of principles and is goal-oriented. The interests of innovative development determine selection of priorities. The priorities of innovative development are understood as key areas of innovative development, aimed at creating innovative solutions (products, technologies), facilitating increased innovation potential of the country/region/industry, increasing the economic growth rate and increasing the living standard of the population (Figure 1).

In Russia, the priorities of innovative development of agribusiness are defined in the Strategy of Innovative Development of the Russian Federation for the period of up to 2020, the Strategy of scientific and technological development of the Russian federation for the period of up to 2035, national program Digital Economy, sectoral project Digital Agriculture [6].

Due to that, the authors think that the main priorities in innovative development of agribusiness are:

1) a complex introduction of digital/smart technologies in all the sectors of agriculture, as well as in storage, processing and transportation of agricultural production; introduction of IoT technologies, robotics in production and management functions;

2) a transition to environmentally safe, resource-saving technologies, development and implementation of innovative 
technologies of recycling, use of alternative energy sources; production of environmentally safe agricultural food products by means of using innovative preparations;

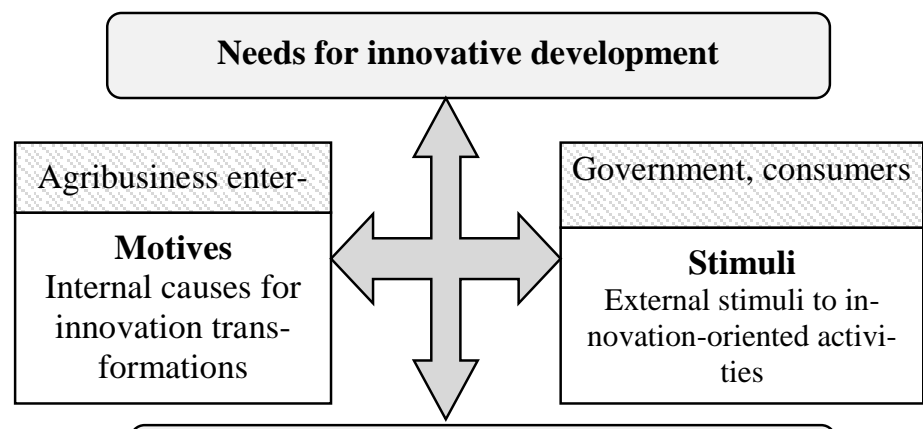

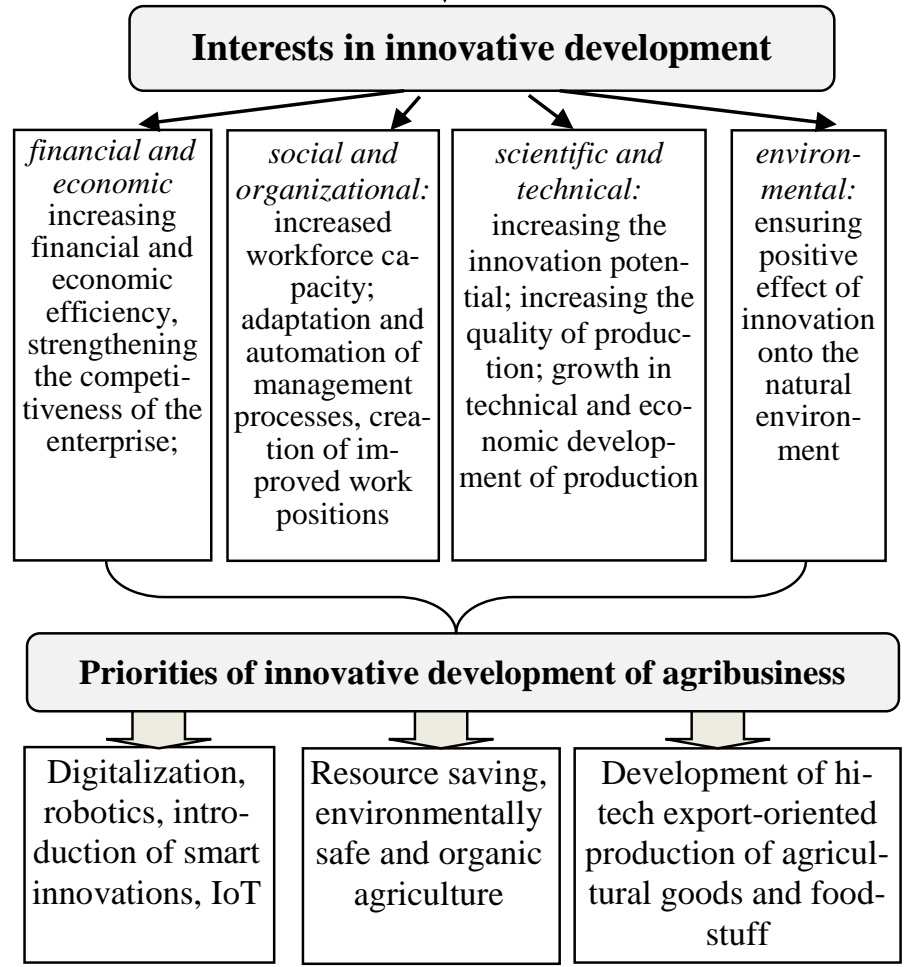

Fig. 1. Key innovative interests and priorities of innovative development of agribusiness

3) development of hi-tech export-oriented enterprises on the basis of upgraded processing plants; development and implementation of innovative biotechnologies in deep processing of crop farming products; formation of a digital platform for support of agricultural export.

In order to attain the selected priority objectives and total use of digital technologies, growth of innovation activity of all economic forms in agribusiness, it is necessary to have a welldeveloped innovation environment, important components of which are scientific and educational environment. An adaptive mechanism is needed to support innovative development of agribusiness that may quickly react to changes in global science and economy [7-8]. Recent events related to COVID-19 pandemic also showed a necessity to develop tools and methods aimed at reducing the impact of pandemics onto the agricultural and food processing sector, namely, suspended export and import of innovation products, closure of large processing plants with high concentration of workers, abnormality in supply of food products and resources due to limits in operation of logistics companies.

\section{RESULTS AND DISCUSSION}

A foundation of digitalization and innovation in agribusiness in scientific and technical activity aimed at ensuring stable and efficient operation of domestic agricultural producers and increasing the competitiveness of the Russian agricultural and food products in both domestic and international markets. Thus, the Russian agricultural science has an undeniable role in actualization of innovation priorities, as it performs fundamental and applied research and creates new innovative knowledge (Figure 2).

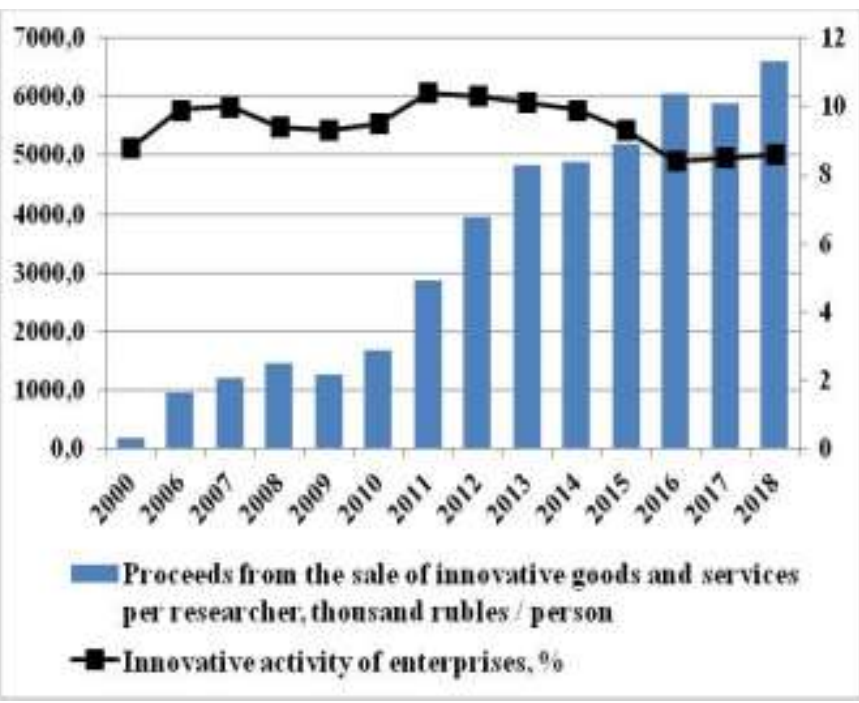

Fig. 2. Principal indicators of innovative development of Russia [9]

A study of innovation development has shown a reduction in the number of organizations involved in research and development in 2018 in comparison with 2000 by $3.6 \%$ (149 units) and a reduction in the workforce of researchers by $23.1 \%$, or by 205.1 thousand people. At that, turnover of innovative goods (services) increased by a factor of 29 during the same period Against this background, reduction of innovative activity by 0.7 percentage points may be explained by organization and structural transformations, insufficient efficiency of innovation management, in particular under developed system for monitoring and evaluation of new competitive innovative technologies [10].

From 2010 to 2018, expenses for scientific research in agricultural sciences increased by 1.9 times, while their proportion in the total amount of expenses reduced by 0.1 percentage points (Table 1).

TABLE I. INTERNAL OPERATING EXPENSES FOR RESEARCH AND DEVELOPMENT IN RUSSIA [9]

\begin{tabular}{|c|c|c|c|}
\hline \multirow{2}{*}{ Year } & \multirow{2}{*}{$\begin{array}{c}\text { Total, billion } \\
\text { rubles }\end{array}$} & \multicolumn{2}{|c|}{ including agricultural sciences } \\
\cline { 3 - 4 } & 489.5 & 8.9 & \% of total \\
\hline 2010 & 873.8 & 13.9 & 1.8 \\
\hline 2016 & 950.3 & 14.2 & 1.6 \\
\hline 2017 & 960.7 & 16.7 & 1.5 \\
\hline 2018 & \multicolumn{2}{c}{} \\
\hline
\end{tabular}


Uniqueness of Russia lies in presence of a huge natural resource and workforce potential characterized by a wide variety of natural and climatic conditions, vast fertile land areas, significant bioresources, as well as a large intellectual potential. However, the available potential is often underutilized, as the analysis shows that often the innovation processes of digitalization cover only one (production) area of an enterprise. While implementing modern technologies, managers often forget to account for necessity of parallel changes in organizational design of the enterprise, importance of training and retraining of personnel, introduction of social innovations, and use of smart technologies in marketing activities of the enterprise. Introduction of new forms of statistical accounting of innovative activities in agribusiness allowed analyzing individual aspects of innovative development of agricultural enterprises in 2017-2018 (Figure 3-4).

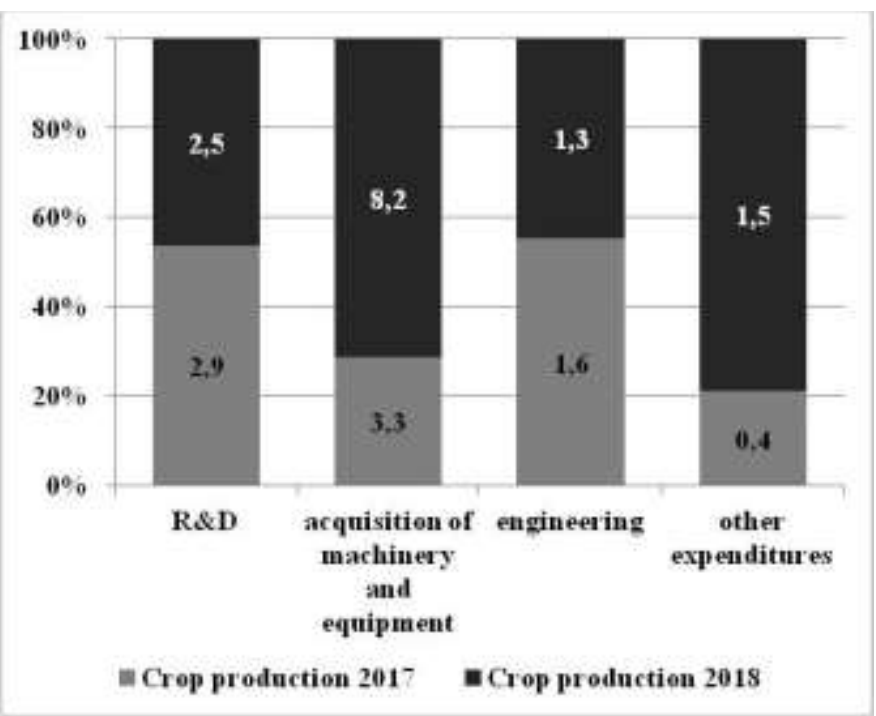

Fig. 3. Composition of costs for technological innovations of agricultural entities in crop farming [9]

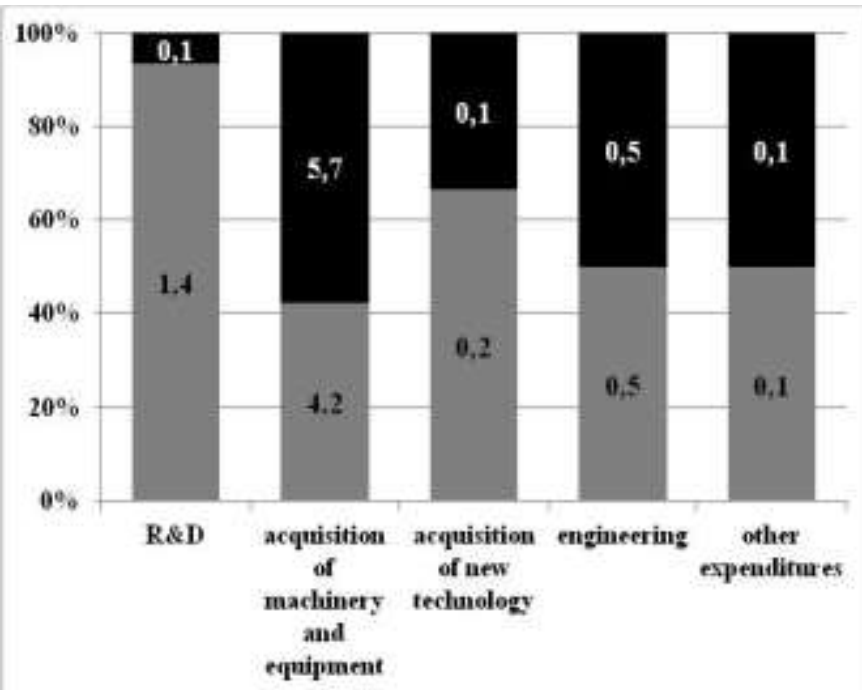

= Animal production 2017 Animal production 2018

Fig. 4. Composition of costs for technological innovations of agricultural entities in animal farming [9]
The cost analysis conducted shows that innovations are largely concentrated in production; in particular enterprises are limiting themselves to implementation of only technical and technological innovations At that, such areas as acquisition of software, workforce development and marketing stay untouched by innovative transformations.

Despite the active governmental innovative policy and implementation of strategic and program measures, agribusiness shows lower indicators of innovation development in comparison with other sectors of the nation's economy. All these facts determine a necessity to develop a mechanism for actualization of set priorities of the innovative development of agribusiness (Figure 5).

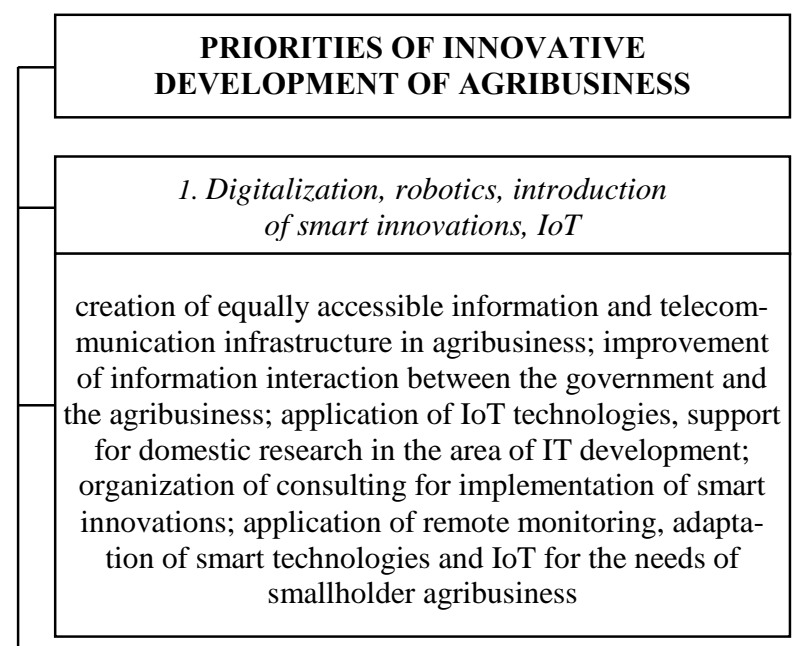

2. Resource saving, environmentally safe and organic agriculture

a complex implementation of innovative breakthrough projects for digitalization of agribusiness, development of private-public partnerships in recycling (recycling and disposal of animal farm waste); preferential loans, compensations for producers using alternative sources of energy; preparation of innovationconscious managers and specialist to master innovations; support to production of environmentally safe products; reduction of environmental footprint

3. Development of hi-tech export-oriented production of agricultural goods and foodstuff.

development of innovative export infrastructure, digitalization of logic systems; formation of exportoriented agrarian technopark formations; development of biotechnologies in the area of food production; support for implementation of innovations in production of export-oriented products; tax preferences for enterprises producing environmentally safe products for export

Fig. 5. Actualization mechanism for priorities of innovative development of agribusiness 
Stimulation of digitalization and implementation of innovative technologies assumes using a complex set of organizational and economic tools, aimed primarily at improvement of the innovation management system at the federal, regional and municipal levels, as well as a coordinated formation of necessary conditions for attaining innovative priorities:

1. Formation of innovation environment shall be aimed at development of innovative infrastructure, at creating of experimental and demo sites, centers for management consulting and training of high quality consultants for working with smallholder agribusiness. It is necessary to create and support the activity of integrated scientific and educational centers, hi-tech innovation clusters that will facilitate integration of science and education, as well as formation of a progressive scientific, educational and technical environment of agribusiness, serving as a foundation for its innovation development [10-11].

Low level of scientific and practical knowledge about innovative technologies and possibility of their implementation among the most part of family farm owners, as well as specialists of smallholder farms determines weak penetration of many intellectual digital solutions into agriculture. In the meanwhile, modern IoT technologies, remote monitoring of production processes would allow developing relevant predictions for future outputs, concluding contracts for delivery of production before harvesting, accelerating the process of managerial decision-making [10].

2. Buildup and efficient use of innovation potential of the agribusiness on the basis of strengthening the resource supply of digitalization and innovative development by means of [12-14]:

- support of efficient reproduction of innovationconscious workforce, buildup of scientific potential, stimulation of breakthrough scientific research among young researchers, workforce training for state management in the area of innovations [15-17];

- attracting investment into agricultural education, development of human capital in the rural territories.

3. Prediction, assessment, arrangement of monitoring and development of measures aimed at liquidation and prevention of social and environmental consequences of digitalization, implementation of genetic technologies and other innovative biological preparations.

Use of intensive technologies in agribusiness enterprises facilitated appearance of serious environmental problems: soil erosion, loss of fertility due to excessive placement of mineral fertilizers, uncontrolled use of aggressive plant-protecting chemicals, waste water pollution as a result of incorrect storage of animal farm waste, disturbance of ecological equilibrium due to use of genetically-modified organisms, as well as introduction of new species of animals and plants from other climatic zones.

Thus, implementation of resource-saving environmentally safe technologies and process recycling has a minimal effect onto the natural ecological system and facilitates rebuilding of natural resources.
4. Development of innovation marketing that includes development of a set of tools for innovation market and studies of customer motivation, measures for promotion of domestic developments to both Russian and global market.

At the same time, increased availability of implementing information technologies for agricultural producers is linked to certain costs that include expenses for formation of internal information system in a short time frame. It should be noted that a long-term study within the framework of monitoring the implementation of Priority National Project and State Program for 2013-2020 allowed identifying a trend to aging among small businesses managers. That is why active implementation and use of IT is hampered due to a general low level of training of managers and software specialists, as well as high prices for special software [18-19].

This function may be performed by consumer cooperative that perform information consulting services in the area of their charter activity or information consulting centers created on the initiative of the entrepreneurs themselves. For example, in developed European countries, sectoral unions and association were formed long time ago and they facilitate activation of innovative activity (developments in genetics, selection, etc.). These structures have an independent status and are managed by elected members.

Improvement of information, scientific and practical support includes the following measures:

- performance of complex and systemic monitoring of digital technology application in agricultural and related enterprises;

- organization of information and communication space, development of telecommunication networks;

- organizing training and further training courses, training workshops for managers and specialists of small and medium agricultural enterprises;

- development of intersectoral interaction on the basis of creating hi-tech innovative clusters facilitating creation and promotion of innovative breakthrough technologies in agricultural and food industry by means of pooling resources and unique knowledge [19];

- formation of innovative breakthroughs in exportoriented enterprises;

- provision of technical support to farmers to master smart innovations.

\section{CONCLUSION}

The existing political and economic conditions in the Russian and global agrarian economy determined by sanctions, reciprocating embargo, decreased production growth rate due to the pandemic, as well as environmental orientation of the global community brings forward a requirement to balance all the innovation processes. Balanced innovation development assumes selection of an optimal vector of development, capable of ensuring equidirectional development of all agribusinesses, stable sustainable growth with minimal social and environmental consequences for the society. 
In order to ensure the digital production and transition to innovative way of development, it is necessary to stimulate and implement innovative breakthrough technologies by all the economic entities of the scientific and technical area of agribusiness. In order to improve the results of innovative activities in agribusiness enterprises, it is necessary to identify break points during the development of innovation development priorities and introduce organizational and economic tools that eliminate such weak points.

Implementing a system of complex management robotic automation in agribusiness provides transparency and controllability of processes, reduced the impact of human error, improves current accounting of expenses and incomes, reduces liabilities, provides objective analysis of financial and economic results of operation.

Thus, in the current conditions, when the main national priorities are food security and increased export of agricultural food products, ensuring production growth is possible only by means of implementation of technical, procedural, organizational and economic innovations, development of domestic selection, increased genetic potential, introduction of smart technologies (smart field, smart storage, etc.); creation of scientific and producing clusters, as well as by digitalization of logistics infrastructure.

\section{References}

[1] A. Smith, Research on the nature and causes of the wealth of peoples and nations. Moscow, 1956

[2] J. Schumpeter, Theory of economic development. Progress, 2005.

[3] E. Toffler, Third wave. Moscow: AST, 2010.

[4] B. Twiss, Scientific and technological innovation management. Moscow: Economika, 1989.

[5] M.U. Porat, The Information Economy: Definition and Measurement Washington, DC: US Government Print. Office, 1977.
[6] Departmental project "Digital Agriculture": official publication. Moscow: Rosinformagroteh, 2019.

[7] E.V. Truflyak, N.Yu. Kurchenko, A.S. Krejmer, Precision Agriculture: Status and Prospects. Krasnodar: KubSAU, 2018.

[8] V.I. Kiryushin, "Scientific and innovative support of priorities of agriculture development", Dostizheniya nauki i tekhniki APK, vol. 33, no. 3, pp. 5-10, 2019.

[9] Russian Statistical Yearbook. Moscow: Rosstat, 2019.

[10] T.M. El'dieva, "Directions for the use of smart innovation in agriculture", Mezhdunarodnyj sel'skohozyajstvennyj zhurnal, vol. 6, pp. 45-49, 2018.

[11] S. Mitchell, A. Weersink, "Adoption of precision agriculture technologies in ontario crop production Canadian," J. of Plant Sci., vol. 98, pp. 1384-1388, 2018

[12] E.M. Avraamova, Yu.B. Verpahovskaya, "Development of an innovative economy and the problem of training", Ekon. Reg., vol. 2, no. 10, pp. 84-95, 2007.

[13] A. Polukhina, V. Rukomoinikova, "Development of agritourism as an innovative approach to agricultural complex management in Russia", Worldwide Hospitality and Tourism Themes, vol. 10, no. 4, pp. 458-466, 2018.

[14] S. Aubry, C. Eigenmann, "New challenges to digitization of genetic resources for food and agriculture", Agrarforschung Schweiz, vol. 10, pp. 122-127, 2019.

[15] O.V. Mamai, I.N. Mamai, M.V. Kitaeva, "Digitization of the agricultural sector of economy as an element of innovative development in Russia", Lecture Notes in Networks and Syst., vol. 84, pp. 359-365, 2020.

[16] L.E. Krasil'nikova, "Innovative development of agricultural production", Ekon., trud i upravl. v sel'skom hoyazjstve, vol. 1, no. 46, pp. 49-57, 2019.

[17] El. Bilali, M. Allahyari, "Transition towards sustainability in agriculture and food system: Role of information and communication technologies", Inform. Proc. in Agricult., vol. 5, pp. 456-464, 2018.

[18] I.P. Belikova, D.V. Zaporozhets, A.V. Tenischev, O.S. Zvyagintseva, A.P. Isaenko, "Innovative development of the agricultural sector: problems and prospects", Res. J. of Pharmac., Biolog. and Chem. Sci., vol. 9, no. 6, pp. 1860-1865, 2018.

[19] A.E. Karlik, V.V. Platonov, "Intersectoral territorial innovation networks", Econ. Reg., vol. 12, no. 4, pp. 1218-1232, 2016. 